\title{
HOME DEFENCE AND THE SANDYS DEFENCE WHITE PAPER, 1957
}

\author{
Matthew Grant
}

Long understood as the key document in Britain's cold war history, the Sandys Defence White Paper of 1957 nevertheless has a largely forgotten context: home defence. This article argues that understanding this context allows important new conclusions to be drawn concerning the drafting, presentation and the reception of the document and the deterrent strategy it expounded. It argues that the Paper failed to establish a new doctrine for civil defence which reconciled the policy with the wider deterrent strategy. In doing this, the Paper presented a muddled policy to the public: one which failed to justify the reductions in civil defence provision but which stressed the destructive power of thermonuclear weapons. This had the effect of encouraging the critics of the Government's nuclear strategy to flag the absence of adequate civil defence measures and highlight the 'admission' that there was no defence against the hydrogen bomb.

\section{Introduction}

The Sandys White Paper was the key defence document in Britain's cold war history. It was the pivot on which British policy turned. Before 1957, a conscript army had continued from the Second World War to fulfil British defence commitments. Afterwards, Britain finally and fully embraced the doctrine of nuclear deterrence as the key organising concept of its defence posture. This allowed widespread cuts: military personnel would be reduced from 690,000 to 625,000 within twelve months, and to 375,000 by the end of $1962 .{ }^{1}$ The British commitment to Europe enshrined in the British Army of the Rhine (BAOR) was slashed, the surface fleet was cut back, and the strength of Fighter Command was reduced. For a generation of young British men, Sandys called an end to National Service, ensuring that none would be compelled to undertake military service for the rest of the twentieth century. Finally, Sandys'

\footnotetext{
I would like to acknowledge the aid of the Arts and Humanities Research Council for funding the research on which this article is based and the assistance of Dr Tracey Loughran for reading an earlier version of this paper.

${ }^{1}$ Ministry of Defence, Defence: Outline of Future Policy, Cmnd.124, (London: HMSO, 1957), p.7.
} 
unambiguous commitment to the nuclear deterrent inspired a mass-movement which equally unambiguously rejected nuclear weapons and campaigned to have the British deterrent scrapped.

The importance of these four main strands (the heavy reduction in conventional military forces, the ending of conscription, the commitment to nuclear deterrence, and the fostering of anti-nuclear sentiment) varied greatly in the thinking of the Conservative Government in 1957, but have all been the subject of historical enquiry. For example, rows about the cuts in conventional forces dominated the formulation of the White Paper with the Chiefs of Staff bitterly opposing the reductions. The paper went through no less than thirteen 'final' versions, and as Peter Hennessy has put it, 'there was blood on every page'. ${ }^{2}$ This aspect of Sandys has attracted a good deal of historical attention. ${ }^{3}$ There are also widespread assumptions about the social consequences of ending conscription. Writers on the 1960s have long since considered the point when the last National Servicemen left uniform a key cultural moment. As Christopher Brooker put it in 1969 , 'the social consequences of the decision to place so much store by [the] "independent nuclear deterrent"... were in many ways to be even greater than its political and military repercussions' ${ }^{4}$ On the adoption of the doctrine of nuclear deterrence, the revolutionary nature of Sandys can be overstated. British strategy had incorporated the notion of deterrence for some years. It was pretty well fully articulated in the 1955 White Paper, for example, which argued that nuclear weapons brought not despair but hope. ${ }^{5}$ New in 1957 was the argument that a deterrent posture allowed concomitant reductions in conventional forces. Again, the origins of the Sandys Paper's nuclear commitment has been mined in some important works. ${ }^{6}$

Lastly, there are the political consequences of this deterrent doctrine; or perhaps it would be better described as the political consequences of the way in which this

\footnotetext{
${ }^{2}$ P. Hennessy, Having it So Good: Britain in the Fifties, (London: Penguin, 2006), p.465.

${ }^{3}$ M. S. Navias, 'Terminating Conscription? The British National Service Controversy, 1955-56', Journal of Contemporary History, 24:2 (1989), 195-208; M. Carver, Tightrope Walking: British Defence Policy since 1945, (London: Hutchinson, 1992), pp.41-59.

${ }^{4}$ C. Brooker, The Neophiliacs, (London: Collins, 1969), p.117; see also R. Weight, Patriots: National Identity in Britain, 1940-2000, (London: Pan, 2003).

${ }^{5}$ Ministry of Defence, Statement on Defence, 1955, Cmd.9391, (London: HMSO, 1955), p.4.

${ }^{6}$ M. S. Navias, Nuclear Weapons and British Strategic Planning, 1955-58, (Oxford: Clarenden, 1991); S. J. Ball, 'Harold Macmillan and the Politics of Defence: the Market for Strategic Ideas during the Sandys Era Revisited', Twentieth Century British History, 6:1 (1995), 78-100;
} 
doctrine was announced. It is a commonplace in the literature on the Campaign for Nuclear Disarmament to stress its origins in the Sandys White Paper's famous admission that 'it must be frankly recognised that there is at present no means of providing adequate protection for the people of this country against the consequences of an attack with nuclear weapons'. ${ }^{7}$ Yet the reasons why such an admission was made have yet to be sufficiently probed: after all, a deterrent posture did not preclude the government continuing its previous argument that home defence would go a long way to mitigating the effects of nuclear attack. The importance of this phraseology, both within the report and for its reception, can be seen in a fifth and neglected effect of the Sandys White Paper: the slashing of the civil and home defence budget by over $50 \%$.

The purpose of this article is to explore the home defence context of the Sandys White Paper. It argues that 'passive' defence against nuclear weapons is the White Paper's forgotten paradigm and had an enormous effect on how the wider policy of deterrence was framed and expounded. The cuts in civil defence expenditure represented a revolutionary break with the pre-1957 policy of providing 'survival measures' and required justification beyond the merely financial, and this was achieved by linking reduced provision to the new deterrent posture. But despite the White Paper stressing the need for continued civil defence measures as an insurance, the Government's policy was swept away by the 'admission' that there was no adequate defence against hydrogen bombs; moreover, the civil defence passages of the paper, culled of all policy announcements or even of existing measures, were certainly not strong enough to convince anyone that the Government believed in civil defence as a viable policy. Later, the admission would be seized upon by the disarmament movement as a stick with which to beat the deterrent policy itself. Also, the home defence aspect of the Sandys White Paper sheds interesting new light on the report's formulation, and suggests that more emphasis should be placed on its pre-Suez origins than is currently the case. While its role as post-Suez review is not in doubt, it is clear that much of the philosophy of the White Paper was thrashed out in the historiographically neglected 1956 Policy Review conducted by the Eden Government. By examining the role of civil defence in the Government's nuclear policy up until 1956, its reappraisal and downgrading in the Policy Review, and finally its justification in the Sandys White

\footnotetext{
${ }^{7}$ Ministry of Defence, Defence: Outline of Future Policy, p.2.
} 
Paper and reception in the following eighteen months, a deeper understanding of the Government defence policy can be achieved and the origins and consequences of the Sandys White Paper more fully understood.

\section{Civil and Home Defence, 1945-56}

Before Sandys, civil defence had commanded an important, if increasingly ambivalent, space in the cold war British state. Its position owed much to the specific nature of weapons technology when the cold war began. Having proved an indispensable part of the Second World War state machinery, ${ }^{8}$ it was naturally assumed to be equally, if not more, important in the early years of the cold war. Initial planning to meet a future threat began in late 1945, proceeding at a slow pace until the Berlin Crisis of 1948 punctured the leisurely progress of civil defence planning. ${ }^{9}$ That summer, an emergency plan was hastily put together, ${ }^{10}$ and over the next twelve months, a Civil Defence Act (1948) was passed requiring local authorities to implement civil defence measures, and a voluntary Civil Defence Corps was created (1949). The civil defence measures of the later 1940s, including evacuation planning, plans for the 'due functioning' of essential industry and the creation of additional port facilities, were designed to enable Britain to continue to fight (and supply the Army) in a major European war. ${ }^{11}$ In 1948 it was believed that until the mid-1950s the Soviet Union would have only a limited number of atomic weapons with which to supplement its overwhelmingly conventional methods of air attack; as it became clear the Soviet atomic stockpile would far exceed this, the centrality of civil defence began to fracture before the original policy could be implemented. By 1953, although the rearmament inspired by the Korean War saw a massive hike in civil defence spending, it was clear that the 'atomic' civil defence as previously envisaged could not hope to save Britain from the crippling effects of air attack. At this point it was believed that in a future war

\footnotetext{
${ }^{8}$ T. O'Brien, Civil Defence, (London: HMSO, 1955).

${ }^{9}$ M. Grant, 'Civil Defence Policy in Cold War Britain, 1945-68'. Unpublished PhD Thesis, Queen Mary, University of London, 2006.

${ }^{10}$ N[ational] A[rchives, Kew, United Kingdom], CAB 134/82. CDC(48)16, 'Preparations for Civil

Defence', Report to the Defence Committee, 19.8.1948.

${ }^{11}$ Grant, 'Civil Defence Policy'.
} 
an attack on the United Kingdom would kill 1.3 million people and cripple the nation's infrastructure, thus ending all hope of supplying the BAOR. ${ }^{12}$

Shortly on the heels of this devastating analysis, an even more shocking development ensured that 'life-saving' civil defence on the 1939-45 model was obsolete. Although in scientific terms the first hydrogen bomb was exploded by the United States in November 1952, in terms of its impact on the British cold war state, the hydrogen bomb era began with the American Pacific tests between February and April 1954. The enormous power of the weapon, coupled with the discovery of its deadly radioactive side effects, triggered something amounting panic in Whitehall and beyond. ${ }^{13}$ To countermand the effects of the hydrogen bomb's blast and its deadly radiation, an influential working party was eventually set up to investigate how civil defence could be reconfigured. Chaired by a Treasury official, William Strath, and staffed by a mixture of officials and scientists from the Ministry of Defence and the Home Office, their report - the 'Strath Report' - was delivered in early 1955 and recommended an enormous programme to save the United Kingdom in a future war. ${ }^{14}$ Although the possibility of saving lives through post-attack rescue was remote, Strath believed that through a mixture of evacuation and Treasury-funded domestic shelters, millions could be saved out of the twelve millions estimated casualties arising from an attack with just ten hydrogen bombs. Only if Britain committed enormous sums (around $£ 2,000$ million) to these and other 'survival' measures, such as food and medical stockpiles, could the British state hope to emerge through a thermonuclear war intact. ${ }^{15}$

Before Strath had reported, Coventry City Council announced that it would stop all civil defence measures as, in the Town Clerk's words, 'in view of the recent reports in regard to the explosion of the hydrogen bomb and its devastating effects... it is a waste of public time and money'. ${ }^{16}$ The Councillors were attacked in scathing terms by the Daily Mail on 8 April 1954, which called them 'conceited little men who, because they

\footnotetext{
12 NA, CAB 134/938. HDC(53)7, 'The Initial Phase of a War', Report by the Home Defence Committee Working Party, 24.7.1953.

${ }^{13}$ For example see NA, CAB 130/101. GEN 461/1 ${ }^{\text {st }}$ Meeting, 12.3.1954; P. Hennessy, The Secret State: Whitehall and the Cold War, (London: Penguin, 2003), p.50.

${ }^{14}$ NA, CAB 134/940. HDC(55)3, 'The Defence Implications of Fallout from a Hydrogen Bomb', Report by a Group of Officials, 8.3.1955; for background, see J. Hughes, 'The Strath Report: Britain Confronts the H-Bomb, 1954-5', History and Technology, 19:3 (2003), pp.257-75.

${ }^{15}$ Grant, 'Civil Defence Policy'.

${ }^{16}$ NA, HO 322/136. Letter from the Town Clark, Coventry, to the Home Secretary, 7.4.1954.
} 
have been elected to a local council, think they have a mandate to run the world' ${ }^{17}$ The row was resolved by the Home Secretary, Sir David Maxwell Fyfe, exercising his right (enshrined in regulations made under the 1948 Act) to appoint commissioners to undertake the Coventry's civil defence functions 'in the name and at the expense of the said Council'. ${ }^{18}$ Churchill approved, declaring that the Council should be treated 'with the utmost censure which the law allows. What a mean and cowardly gesture for a city to refuse to give humanitarian aid to neighbouring towns in distress, at the same time expecting help themselves'. ${ }^{19}$

When Strath reported a major political battle took place which demonstrated some of the major faults with the British cold war state. In short, advocates for the 'full Strath' eventually numbered just one: the Home Secretary, Gwilym Lloyd-George. Shelters were simply too expensive (total bill: $£ 1,250$ million), and although Lloyd-George fought an impressive rearguard action in late 1955 to ensure stockpiling and other 'survival' measures were implemented throughout 1955, he failed to secure even the first, and smallest, instalment ( $£ 78$ million) of his desired $£ 628$ million over seven years. Lloyd-George's fellow ministers had agreed in principle with the desirability of thoroughgoing civil defence measures, but the economic circumstances of the post-1955 election boom ruled it out. ${ }^{20}$ For example, Strath was endorsed as the basis of war planning by the Defence Committee in early $1955,{ }^{21}$ and even when rejecting his stockpiling budget it accepted in principle the need for his seven year plan. ${ }^{22}$

Despite the hard-fought compromise, there were important strains of opinion forming against civil defence, especially in the Ministry of Defence. For example, LloydGeorge argued in October 1955 for shelters to be constructed on the grounds that without them civilian morale would collapse: there would be little point in 'keeping forces for the "hot war" if the morale of this country is to collapse and we lose the will to fight'. ${ }^{23}$ Opinion in Air Ministry, however, questioned how many casualties these shelters would avoid in London (the planned shelters, designed to protect against

\footnotetext{
17 'A Bomb and a Town', Daily Mail, 8.4.1954.

${ }^{18}$ NA, HO 322/136. 'Civil Defence: City of Coventry', Order by David Maxwell Fyfe, 24 July 1954

${ }^{19}$ NA, PREM 11/607. Churchill to Maxwell Fyfe, 15.7.1954

${ }^{20}$ NA, CAB 134/1245. HD(M)(56)1, 'Defence Expenditure by Civil Departments', Memorandum by the Chairman of the Home Defence (Ministerial) Committee, 3.1.1956.

${ }^{21}$ NA, CAB 21/4350. 'Central War Plans Secretariat', Note from Strath to Chilvers, 13.5.1955.

${ }^{22} \mathrm{NA}, \mathrm{CAB} 134 / 1245$. HD(M)(56)1, 'Defence Expenditure by Civil Departments'.

${ }^{23}$ Ibid. HD(M)(55)10, 'Shelter Policy', Note by the Home Secretary, 25.10.1955.
} 
fallout, would be quite useless against the blast of the hydrogen bomb), and whether they would really improve morale. ${ }^{24}$ The opinion was also growing within the defence establishment that any large sums spent on passive defence would eventually have to compete with funds spent on the deterrent and conventional forces. ${ }^{25}$

Thus we can see that in many ways civil defence was in an anomalous position in the early months of 1956. Although no real strand of opinion existed within Whitehall calling for an end to civil defence measures, the recommendations of the Strath Report were in tatters: shelters had been comprehensively rejected and 'minimum' survival measures requested by Lloyd-George had not been met in full. It was a classic compromise, a half-measure. The whole doctrine of the policy was to save as many lives as possible, both before and after the attack, but such a policy was in ruins due to a lack of money. It is not surprising that the forthcoming year saw increasing calls for a new conceptualisation of civil defence. But despite this ambiguity, civil defence remained an integral part of the state's response to the cold war threat; moreover, it was a key part of the public response to that threat. Since 1945 civil defence had continuously been stressed as a part of Britain's vital preparations in case of future war; the need for voluntary training was pressed after the founding of the Civil Defence Corps in 1949, using language and images familiar from the Second World War. ${ }^{26}$ Since 1953, the annual Defence White Papers had included reassuring paragraphs on civil and home defence (for this purpose, they were essentially synonyms) stressing the measures which had been taken which would save lives in a future atomic war. In short, the government's discourse on nuclear war had included emphasising some public protection, and when later in 1957 this promise of protection was seemingly withdrawn, or least enormously undermined, there could not fail to be important political and social consequences.

\section{The Policy Review 1956}

\footnotetext{
${ }^{24}$ NA, AIR 8/1836. 'Brief for Under Secretary of State for Air and the Chief of the Air Staff on Shelter Policy', 6.12.1955.

${ }^{25}$ Ibid. See also the thoughts of General Brownjohn, NA, CAB 134/1245. HD(M)(55) $2^{\text {nd }}$ Meeting, 27.10.1955.

${ }^{26}$ Grant, 'Civil Defence Policy'.
} 
Shortly after the major decisions on home defence had been taken in late 1955 and early 1956, the Eden Government began a major review to consider what changes could be made in British policy, considering the nation's economic circumstances and given that it was now believe general war would be unlikely due to the destructive power of the hydrogen bomb. ${ }^{27}$ Never fully completed because of Suez, the Policy Review's (PR) attempt at reconciling foreign policy aims with domestic policy and Britain's economic weakness (especially in terms of strategy) had important repercussions for the following year's White Paper, but has failed to receive the attention it deserves. ${ }^{28}$ It did not seek a dramatic reorientation of Britain's political or economic strategy, but argued this strategy was endangered by the excessive burdens placed upon the economy:

it is clear that since the end of the war we have tried to do too much with the result that we have only rarely been free from the danger of economic crisis... Unless we make substantial reductions in the Government's claims on the national economy we shall endanger our capacity to play an effective role in world affairs. We must therefore concentrate on essentials and reduce other commitments. Only thus shall we be able to find the means to place our economy on a stable basis and to counter the new forms of attack with which we are being confronted. ${ }^{29}$

Integral to this process was the belief that Britain and the world were at a crucial juncture in the cold war: 'the hydrogen bomb has transformed the military situation. It has made full-scale war with Russia or China unlikely. And conventional forces, though still of great importance in some situations, have become a relatively less important factor in world affairs' ${ }^{30}$ Although couched in terms of needing to meet the 'political and material' challenge of communism threat in the 'era of competitive coexistence', PR clearly imagined some sort of post-Geneva moment in which British defence commitments could be scaled back without damaging Britain's strategic position. Possession of the deterring hydrogen bomb, belief in the lessening importance of conventional forces and a parallel increase in the need for inexpensive 'political' initiatives, all seemed to fit nicely with the pressing economic need for cuts.

\footnotetext{
${ }^{27}$ The 'master document' of this review was NA, CAB 134/1315. PR(56)3, 'The Future of the United Kingdom in World Affairs', 1.6.1956.

${ }^{28}$ K. Ruane and J. Ellison, 'Managing the Americans: Anthony Eden, Harold Macmillan and the Pursuit of "Power-by-Proxy" in the 1950s', Contemporary British History, 18:3 (2004), 147-67 is a notable exception.

${ }^{29} \mathrm{NA}, \mathrm{CAB} 134 / 1315$. PR(56)3, 'The Future of the United Kingdom in World Affairs'.

${ }^{30}$ Ibid.
} 
Although many of the important strategic decisions announced in the 1957 White Paper were still to be decided - and the exact levels of manning and spending were painfully thrashed out after Macmillan became Prime Minister and Sandys Minister of Defence on a more basic level it was understood that big reductions were needed and that the new hydrogen bomb allowed them to be made. Richard Powell, Deputy Secretary of the Ministry of Defence at the time, believed that, 'there was a feeling [around 1956-67], when the impact of nuclear weapons finally broke through, that the nuclear deterrent was not only going to deter global war in Europe, but every kind of military incident'. ${ }^{31}$ Macmillan, Chancellor when PR was meeting, was relieved, noting in his diary that 'the military are beginning not only to talk about the Hydrogen Bomb strategy but to contemplate putting it into effect'. ${ }^{32}$

Of more immediate concern for Macmillan was the pressing need for savings of $£ 100$ million in government expenditure. 'The $£ 100$ million' dominated the domestic business of the government throughout the summer months and even before Suez diverted Ministerial attention from the review, PR had neglected its longer-term strategic aspects and become more concentrated on Macmillan's expenditure demands. But whereas most of the policy changes implicit in PR's initial deliberations had to wait until 1957, it had sufficiently set the strategic agenda to see an enormous cut in civil and home defence provision. This cut was demanded by Macmillan on financial grounds, and contributed greatly to his $£ 100$ million, but it was also acceded to on strategic grounds, demonstrating, as we shall see, a deep belief in the deterrent value of the nuclear weapon.

Of integral importance was the belief expressed by Eden that 'we must now cut our coat according to our cloth... there is not much cloth' and specifically that 'in our defence programme generally we are doing too much to guard against the least likely risk, viz. the risk of major war'. ${ }^{33}$ In response to Macmillan's demands, a report on civil and home defence was produced by the Sir Walter Monckton, the Minister of Defence. Lloyd-George, ${ }^{34}$ the Minister responsible for civil defence, was excluded from the PR

\footnotetext{
${ }^{31}$ Sir Richard Powell in 'The Move towards the Sandys White Paper of 1957', seminar held July 1988, (Institute of Contemporary History, 2002, http://www.icbh.ac.uk/icbh/witness/sandys/), p.29

${ }^{32}$ P. Catterall (ed.), The Macmillan Diaries, (London: Pan, 2004), p.564, diary entry for 9.6.1956.

${ }^{33}$ NA, CAB 134./1315. PR(56) $1^{\text {st }}$ Meeting, 6.6.1956.

${ }^{34}$ See NA, PREM 11/4111. Sewlyn Lloyd to the Prime Minister, 28.7.55
} 
Committee on the grounds that Monckton was officially responsible for co-ordination of all defence measures. Thus Monckton was able to recommend swingeing cuts in LloydGeorge's budget, reducing 'defence expenditure' but maintaining his own departmental allocation. $^{35}$ In fact Monckton's strategy earned him a rebuke by Eden the following month, the text of which implied that Monckton was not ensuring a fair allocation of resources within the defence budget for home defence and, crucially, he was attempting to deal with the Home Secretary in manner he dealt with the service ministers. ${ }^{36}$ The experiment of Ministry of Defence overlordship was scrapped the following year. ${ }^{37}$ Monkcton's proposed PR cuts involved a variety of measures, but mainly rested on cutting all stockpiling expenditure, to contribute some $£ 12$ million (including some $£ 5$ million already previously agreed) to 'the $£ 100$ million' of cuts in the current financial year.

Monckton also argued that further cuts would follow in future years as home defence was radically overhauled. By discontinuing expenditure 'designed to enable us to "survive" a war and to "recover", enormous savings could be made. Monckton's only caveat was that 'our discontinuance of these preparations should not be so abrupt as to cause a shock to our allies and our own public'. All that should be continued were 'those home defence preparations the absence of which would be liable to undermine the deterrent'. These were: measures for the continuity of government and control of the population, communications for air defence and for air-raid warning, and the maintenance and training of civil defence forces and of military forces allocated to home defence. These three policy strands were needed because without them 'all central command would come to an end and complete chaos would ensue the moment the first bombs fell' ${ }^{38}$ In all, this would allow home defence spending to fall to under $£ 30$ million in $1957 / 8$ and under $£ 20$ million a year thereafter.

When the PR Committee met on 9 June 1956 Monckton's new policy was approved, and only the abolition of stockpiling raised any concerns. ${ }^{39}$ But hoarding food and medical supplies was deemed to involve 'expenditure on a scale inappropriate to the

\footnotetext{
${ }^{35}$ NA, CAB 134./1315. PR(56)8, 'Home Defence Policy Review', Memorandum by the Minister of Defence, 7.6.1956.

${ }^{36}$ NA, CAB 21/3346. Prime Minister to Minister of Defence, 3.7.56.

${ }^{37} \mathrm{NA}, \mathrm{CAB}$ 134/1476. CD(57)5, 'Terms of Reference and Composition', 19.11.1957.

${ }^{38}$ NA, CAB 134./1315. PR(56)8, 'Home Defence Policy Review'

${ }^{39}$ Ibid. PR(56) $3^{\text {rd }}$ Meeting, 9.6.1956.
} 
new assumptions on which our defence policy was to be based'. Stockpiling accounted for some $£ 383$ million of the total $£ 629$ million home defence programme agreed in principle just six months previously. Although allowing 'this country to be involved in global war without adequate stocks would be catastrophic', it was considered that 'such a war would be catastrophic in any case - not only to this country but to the human race - and it was unlikely that the presence or absence of stocks would be a material factor in a Government's decision on whether to allow this country to become involved in a global war'. ${ }^{40}$

This abandonment of the traditional conception of home defence as a means to survive and recover from a war did not mean the end of the volunteer civil defence forces. As Monckton put it in his original paper, 'we must continue to take an active interest in civil defence... otherwise the volunteer forces will wither away'. Vitally, 'our policy would not be one of providing a façade, and we must be careful not to think in such terms'. What Monckton meant was the new conception of home defence-maintenance of the deterrent - would have to be explained publicly, and 'that within these limits, our home defence preparations will be realistic and not a façade'. ${ }^{41}$ This could only occur if the Government were prepared to announce the adoption of the new rationale and the abandonment of the publicly held policy that civil and home defence preparations were designed to save lives. Of course, if the government failed to do this then the revised civil defence policy would indeed be a façade, one that would be increasingly difficult to maintain. Herein lies the origins of the controversial passage in the Sandys White Paper that there was no adequate defence and the rather less well remembered section detailing the continued importance of home defence in the thermonuclear era.

In outlining his strategy, Monckton neatly delineated the fundamental difference in doctrine on home defence between the military thinkers in the Ministry of Defence and the domestic strategists in the Home Office. His reasoning was that stockpiling would have no real effect and that the basic requirement of home defence was to convince the Soviets that the British deterrent was viable. The continuation of measures he outlined above would do this: all else would be unnecessary. The Home Office view, in stark contrast, was that civil defence was required to convince the British public that the

\footnotetext{
${ }^{40}$ Ibid.

${ }^{41}$ NA, CAB 134./1315. PR(56)8, 'Home Defence Policy Review'.
} 
deterrent was viable: without life-saving measures, 'defeatism' of the Coventry sort could not be discouraged and that only by sustaining and promoting civil defence could moderate opinion be encouraged to support the deterrent policy and its implications for a future war. Moreover, there was the opinion that civil defence was fundamentally right, that it could save lives and was the only moral option open to the government.

This divergence meant that when the Home Office finally had the opportunity to comment, on 18 June, a bitter argument ensued. Lloyd-George had not been consulted at all over Monckton's paper, ${ }^{42}$ and when he was, it was in the form of a paper suggesting a policy which the Policy Review had in fact already agreed on. ${ }^{43}$ The excluded minister reacted angrily to the suggestion that provision be cut so radically, especially because he had not been informed of the revised strategic assumptions on which the cuts were apparently based. He fumed: 'the fact that the chances of global war are receding is not enough to warrant such a disproportionate cut in the expenditure that has been previously regarded as an absolute minimum'. He despaired that the 'long term plan' on which 'so much thought was given last winter' had been annulled. ${ }^{44}$

Lloyd-George envisaged the dark consequences of such a cut: it was his belief that the voluntary civil defence organisation 'would very soon break up of its own accord' if its work was not placed in the context of a wider, thorough home defence policy of the sort being abandoned by Monckton. Such a cut could 'be justified only if it is the Government's considered view that global war can be discounted altogether' ${ }^{45}$ The Home Secretary's anger was unsurprising. As he put it, the previous home defence policy had been painstakingly put together over the course of many meetings and many months, and had settled on a course of providing the bare minimum necessary to enable Britain to fight and survive a nuclear war. Six months later, this carefully constructed policy was ripped up in less than a week, by a group he played no part in.

\footnotetext{
${ }^{42}$ Ibid. PR(56) $3^{\text {rd }}$ Meeting, 9.6.1956.

${ }^{43}$ NA, CAB 134/1245. HD(M)(56)2, 'Home Defence Policy', Memorandum by the Minister of Defence, 18.6 .1956$.

${ }^{44}$ Ibid. HD(M)(56)3, 'Home Defence Policy', Memorandum by the Home Secretary, 18.6.1956.

${ }^{45}$ Ibid.
} 
Lloyd-George and Monckton restated their arguments when a Ministerial Committee on Home Defence met on 20 June. $^{46}$ In particular, Lloyd-George argued that limiting home defence expenditure to $£ 25$ million 'would make it difficult to convince local authorities and the public that the Government attached any serious importance to home defence preparations'. It was also suggested that the home defence policy envisaged by Monckton could not be met with such limited funds. To reconcile his policy with this view, Monckton called for an official report 'on the possible bases and levels of expenditure on which a coherent home defence policy could be constructed. In the light of such a report, Ministers could decide which policy to adopt and programmes could thereafter be drawn up on the basis of that policy'. ${ }^{47}$ Thus the basis of future policy on home defence was entrusted to a committee of civil servants chaired by the Cabinet Secretary, Sir Norman Brook. Brook had been present throughout the deliberations of the Policy Review meetings, and was more informed than the outcast Lloyd-George on the initial decision to cut home defence provision.

Brook's snap review of home defence, completed within days, reluctantly upheld Monckton's new 'deterrent-only' policy. ${ }^{48}$ Although strongly guided to support the new PR-favoured $£ 25$ million limit, with Brook arguing that as the $£ 100$ million needed for a survival-and-recovery policy was out of the question, an extra $£ 15$ million more 'would largely be money down the drain' as it could not hope to achieve real results', ${ }^{49}$ the Committee reacted strongly to the cut. ${ }^{50}$ It was pointed out that without stockpiles of food, medical supplies or fuel, the home defence effort would collapse: no survivors could be treated and more would probably die of starvation than from the actual enemy attack. $^{51}$

Thus when Brook reported back to the Ministerial Home Defence Committee, he argued that if any money over that supplied to the basic policy could be found, it should be devoted to food stockpiling on the grounds of maintaining the deterrent. Ministers were informed that officials believed expenditure of less than $£ 25$ million was unfeasible, and

\footnotetext{
${ }^{46}$ Ibid. $\operatorname{HD}(\mathrm{M})(56) 2^{\text {nd }}$ Meeting, 20.6.1956.

${ }^{47}$ Ibid.

${ }^{48}$ NA, CAB 134/1246. HDC(56)3, 'Defence Expenditure by Civil Departments', Note by the Chairman, 22.6.1956; Ibid. HDC(56) $1^{\text {st }}$ Meeting, 25.6.1956.

${ }^{49}$ Ibid. HDC(56)3, 'Defence Expenditure by Civil Departments',

${ }^{50}$ Ibid. HDC(56) $1^{\text {st }}$ Meeting, 25.6.1956.

51 Ibid.
} 
that if more could be found stockpiling should be continued, but that the Monckton policy could proceed at a cost of between $£ 25-30$ million a year. ${ }^{52}$ Ministers were warned, however, of the risks such a policy entailed. It would be difficult 'to reinstate quickly any insurance against the failure of the deterrent'. Also, Brook made it clear 'that the absence of an insurance against the failure of the deterrent could not be concealed. In particular, although no information about the size of food stocks is made public, the fact that they were being run down would become widely known' ${ }^{53}$

Lloyd-George's intervention appeared, by the end of June 1956, to have secured an extra few million pounds for his cherished civil defence policy, but even a figure of $£ 25-30$ million meant the end of any notion of 'surviving' and 'recovering' from a nuclear war. Although agreement on this had been forged, there remained a deep and underlying disagreement about the worth of key home defence measures that was not resolved until the next decade. Over 'survival' measures, Lloyd-George, and indeed much of Whitehall, felt a degree of resentment that the basic doctrine of home defence had been overturned so quickly and on financial grounds. The Home Office, for example, was not convinced that survival-and-recovery was impossible or a waste of resources. This had important implications for the debate over the 'deterrent' value of home defence. Monckton and the Ministry of Defence had taken a very narrow view of the issue: only those policies which actively helped the use of the military deterrent were necessary. The Home Office, on the other hand, believed that the continuation of 'survival' measures such as stockpiling food and medical supplies were necessary to maintain the fiction of post-attack preparedness, thus encouraging the belief - both at home and abroad - in British determination to resist aggression, even at the risk of allout nuclear war.

These contradictions were not resolved in the summer of 1956, but short-term acquiescence was secured partly by the threat of an even bigger cut. Macmillan, on 12 July, weighed in by arguing that spending should be capped at $£ 15$ million. ${ }^{54}$ This would mean standing down the voluntary civil defence services 'and have nothing

\footnotetext{
${ }^{52}$ NA, CAB 134/1245. HD(M)(56)4, 'Defence Expenditure by Civil Departments', Report by the Home Defence Committee, 29.6.1956.

${ }^{53}$ Ibid.

${ }^{54} \mathrm{NA}, \mathrm{CAB} 134 / 1315$. PR(56)19, 'Home Defence', Memorandum by the Chancellor of the Exchequer, 12.7.1956.
} 
locally except a nucleus organisation which could be expanded - along with other preparations - if the risk of global war came above the horizon'. Macmillan believed 'that there is sufficient in this programme to show the people of this country and any potential enemies abroad that we are prepared to face a hydrogen bomb attack in the unlikely contingency of global war'. ${ }^{55}$ Such a further cut on this scale was opposed by Brook when he briefed Eden before PR met the following day. ${ }^{56}$ Brook reminded the Prime Minister that the Committee had 'agreed that we should maintain the minimum element of home defence required to support the deterrent', and that this minimum level had been outlined by Monckton and fleshed out by officials and amounted to spending about $£ 25$ million a year. Macmillan’s proposal to stand down the Civil Defence Services 'would have to be justified on the basis that we can see no prospect of an attack on this country for many years to come. It would not be consistent with our defence policy generally'. It would 'at least appear to undermine the deterrent', as well as being difficult to defend publicly; "it would involve admitting Coventry was right ${ }^{57}$ - a shrewd comment by Brook, given the controversy caused by Coventry's actions in 1954.

When PR met on 13 July, Macmillan's proposal was savaged by Monckton and LloydGeorge (invited for the first time). Monckton explained: 'though the risk of global war in the near future might be remote, the possibility of global war could not be ruled out altogether', and the new policy maintained 'a sufficient level of defence preparations to ensure that the deterrent could operate and that the Russians were not led to believe that they could destroy this country in one attack without being destroyed themselves' ${ }^{58}$ Moreover, 'if the Civil Defence Services were stood down it would be impossible to conceal the fact, which would be likely to have a disturbing effect' both on public opinion and on Britain's allies'.59 Lloyd-George, converted to Monckton's plan out of the necessity of defending civil defence from Macmillan's even more devastating cuts, now argued that $£ 25-30$ million a year was the lowest level on which it would be possible to maintain a successful home defence programme'. Moreover, the steady decline in civil defence spending since 1954 had left the 'growing impression that the

\footnotetext{
${ }^{55}$ Ibid.

${ }^{56}$ NA, CAB 21/3508. 'Prime Minister's Brief on PR(56)19, Home Defence', Note by Sir Norman Brook, 13.7.1956.

${ }^{57}$ Ibid.

${ }^{58} \mathrm{NA}, \mathrm{CAB} 134 / 1315$. PR(56)6 $6^{\text {th }}$ Meeting, 13.7.1956.

${ }^{59}$ Ibid.
} 
Government had accepted that nothing could be done about civil defence in global war. There was a risk that a defeatist attitude might spread throughout the country' ${ }^{60}$

Monckton's triumph resulted in a three-year plan based on this policy being completed in December. ${ }^{61}$ When commenting on the plan, Brook informed the Cabinet in January 1957 that the officials most closely involved with civil defence had stressed 'the difficulty of defending a home defence programme which makes no significant provision for the survival of the country in the event of nuclear attack'. ${ }^{62}$ They also suggested 'that it might be easier to justify this programme by reference to the general financial and economic conditions than by reference to any revised appreciation of the risk of global war'. ${ }^{63}$ It was followed up by a remarkable broadside by Lloyd-George. The new policy, he argued in his last Cabinet paper two days before he left the Cabinet alongside the broken Eden, would cause people to conclude that 'the real reason for the reduction is not so much the reduced risk of war as a Government decision that civil defence preparations are of little value' ${ }^{64} \mathrm{He}$ believed that if this view became widespread existing civil defence preparations would be jeopardised, thus undermining the deterrent. Evoking the 'widespread defeatism' felt after knowledge of the hydrogen bomb became public, Lloyd-George warned that only 'reiterated assurances that the Government was still convinced of the value of civil defence' could avert a calamitous collapse of confidence within civil defence and discourage local authorities following the example of Coventry and abandoning civil defence. ${ }^{65}$ This was in stark contrast to Monckton's argument in PR that support for the deterrent would be secured only by boldly stating that civil defence cuts were warranted by the decreased likelihood of global war and the fact that measures existed not to save lives, but to maintain the deterrent.

\section{The White Paper and After}

\footnotetext{
${ }^{60}$ Ibid.

${ }^{61}$ NA, CAB 134/1207. C(O)D(56)23 (Final), 'Defence Expenditure by Civil Departments, 1957/581959/60', Report by the Official Committee on Civil Defence, 30.10.1956.

${ }^{62}$ NA, CAB 129/84. CP(57)5, 'Defence Expenditure by Civil Departments', Note by the Secretary of the Cabinet, 4.1.1957.

${ }^{63}$ Ibid.

${ }^{64}$ NA, CAB 129/84. CP(57)7, 'Home Defence', Memorandum by the Secretary of State for the Home Department, 7.1.1957.

65 Ibid.
} 
After Macmillan became Prime Minister, the defence review began in earnest, although in reality the months leading up to the publishing of the White Paper in April 1957 should be seen as the frenetic end to a long period of continuous review. In these discussions civil defence was understandably pushed to the back of people's minds as the issues of conscription, Fighter Command and others were thrashed out. However, as the White Paper wound its elephantine way around Whitehall throughout March 1957, the new Home Secretary, 'Rab' Butler, became concerned at the treatment of civil defence in the new document. His focus was on two sections; although his official Ministerial interest was restricted to the section on 'Civil Defence', he also scrutinised the section on the 'Nuclear Deterrent' as its discussion of the scale and nature of attack would naturally define how the other paragraphs were received. The changing phraseology of the White Paper in the first spring of Macmillan's premiership illustrates how civil defence was first conceived by the Ministry of Defence, how Butler's concerns were met and a compromise reached, and finally how the importance of civil defence was given greater prominence but failed to lessen the impact of more radical elements of the White Paper.

When the full Cabinet first received a draft of the White Paper on 15 March 1957, it treated civil defence in the manner in which Monckton had analysed it the previous summer. Namely, it was firmly sublimated within the deterrent posture, as indeed was almost everything else in the document. For example, the first paragraphs on the deterrent ran:

Though the Hunters and Javelins of the Royal Air Force would, in the event of war with Russia, be able to take a substantial toll of Soviet Bombers, a proportion would inevitably get through. Even if it were only a dozen, they could, with hydrogen bombs, inflict widespread devastation and might well blot out a large part of the population of the big cities. It must be frankly recognised that fighters cannot give the country as a whole any effective protection against the catastrophic consequences of nuclear attack.

Clearly therefore the central aim must be to prevent war rather than to prepare for it. In present circumstances the only way to deter nuclear aggression is to possess the means of retaliating in time. ${ }^{66}$

${ }^{66}$ NA, CAB 129/86. C(57)69, 'Statement on Defence, 1957', 15.3.1957. 
Thus we can see the origins of the infamous 'no adequate defence' passage lay in an attempt to explain the cutting back of Fighter Command by expounding the new deterrent strategy. Similarly, civil defence was rather tersely explained in the following way:

Passive preparations for nuclear war must take second place to active measures to prevent war; and expenditure on civil defence must as far as possible be curtailed. Nevertheless, plans must be made to enable organised society to survive.

The civil defence services will be maintained, and will be supplied with adequate equipment for training. The work of strengthening essential communications will continue. Research and planning will go forward. ${ }^{67}$

The lack of life-saving measures is implicit, and no-one could remain under the impression that civil defence was considered to be vital aspect of the state's cold war stance. Understandably, one Cabinet critic (presumably Butler as the Minister responsible), stated that 'the treatment of civil defence... would need further consideration, particularly in the light of the statement that the great cities could not at present be defended against nuclear attack' ${ }^{68}$

When the next draft appeared eleven days later, the deterrent section had been amended; it now read: 'it must be frankly recognised that there is at present no means of protecting the people of Britain against the catastrophic consequences of an attack with nuclear weapons.... This grim fact makes it more than ever clear that the overriding consideration in all military planning must be to prevent war rather than to prepare for it' ${ }^{69}$ These omissions changed the sense of the White Paper: whereas before it argued that fighters could not stop bombers delivering their payloads, it now suggested that there was no defence at all from nuclear weapons; whereas before the deterrent strategy (needed to stop bombs being delivered) could have been reconciled with civil defence (needed in case deterrence failed), now the need for civil defence seemed to be contradicted. Although in the published version the key sentence was amended slightly, this had no impact on the overall impression produced by the contrasting sections.

\footnotetext{
67 Ibid.

${ }^{68} \mathrm{NA}, \mathrm{CAB} 128 / 31$. CC(57)21 ${ }^{\text {st }}$ Conclusions, 18.3.2007.

${ }^{69}$ NA, CAB 129/86. C(57)79, 'Statement on Defence, 1957', 26.3.1957.
} 
The rolling series of amendments to the civil defence section also had important consequences. Although the original draft may have lacked nuance, it at least made it absolutely clear that there was a strategic rationale behind the cuts in provision, and that Britain's ability 'to deter nuclear aggression' made civil defence much less important. By the final version of the White Paper this link between civil defence and the deterrent had been lessened as much as the policy's continued worth had been reiterated. Paragraph 21 of the published version read: 'While available resources should as far as possible be concentrated on building up an active deterrent, it would be wrong not to take some precautions to minimise the effects of nuclear attack, should the deterrent fail to prevent war. Civil Defence must accordingly play an essential part in the defence plan'. There followed a brief list of measures which would 'provide a framework for expansion, should that later be necessary'. ${ }^{70}$

Hence the amendments to the original draft had the result of simultaneously: a) undermining the case for civil defence by suggesting that nothing could help the population in a nuclear war; and b) undermining the case for deterrent by stressing the continued need for civil defence in case it failed. In the original draft, the possibility of the deterrent failing was barely raised, and what we can see in the transition from first to final draft is the retreat of the 'Moncktonian' vision of civil defence from its 1956 victory, and advance from the brink of complete defeat of the traditional 'Gwilymian' view - at least in terms of statements in the White Paper. In actuality, of course, civil defence had been severely curtailed, but the original idea expressed within PR was for the sharp decline in civil defence spending to be explained in strategic terms, as evidenced in the original draft of the Sandys Paper. However, when the White Paper was published, the emphasis on the deterrent dominated public discourse on the document; no discussion of civil defence lessened it. Nor did the redrafting of the civil defence sections seem to impinge on the public mind. This is because much more was made of the 'no adequate defence' statement.

No amount of rephrasing of the civil defence paragraphs would have replaced the impression that the government thought civil defence next to useless. In effect the consequences of the White Paper were those Lloyd-George had most feared:

\footnotetext{
${ }^{70}$ Ministry of Defence, Defence: Outline of Future Policy, p.2.
} 
contemporary observers could not have avoided the conclusion drawn by Alistair Horne, Macmillan's official biography, some twenty-two years later: 'home defence was slashed to the bone - on the pessimistic, or realistic, assumption that there could be no effective protection for the civil population on the dreadful power of the new $\mathrm{H}$ Bomb'. ${ }^{71}$ This view certainly became widespread. Although the Government had dressed the language of the White Paper partly to avoid such an impression, the public, as Peter Hennessy has put it, 'could read White Papers and absorb the essential thinking behind them' ${ }^{72}$

The initial press reaction was relatively muted, with newspapers understandably more concerned with the defence cuts and the end of conscription. The editorial of the Daily Mail, in summarising the White Paper's rationale, echoed Stanley Baldwin's famous comment made a quarter of century before: 'the H-bomber will always get through'. ${ }^{73}$ Neither the Times nor the Daily Telegraph mentioned 'the admission' outside of summaries of the document. The Manchester Guardian had it in bold type on the front page ${ }^{74}$ but its leader said 'this is a bold statement, but it will only come as a shock to those who have been cherishing illusions dangerous to themselves' ${ }^{75}$ Within days of the publication of the White Paper in April, however, St Pancras Borough Council decided to follow the example of Coventry in 1954 and renounce civil defence. The row erupted when the Council's General Purposes Committee recommended that civil defence should be stopped because, the Town Clerk informed the Home Office, 'in view of the Government's admission in the recent White Paper that there is no real defence against atomic and hydrogen bomb warfare, we are of the opinion that to continue with civil defence is a complete waste of money'. ${ }^{76}$

An enraged Butler wrote to Sandys the day the St Pancras decision made the evening papers (15 April), informing in his colleague that he had been concerned 'at the construction that had been placed on [the crucial 'no defence' sentence] and its possible effect on the public'. He continued: 'I had hoped that the wording we agreed for the

\footnotetext{
${ }^{71}$ A. Horne, Macmillan: 1957-1986, (London: Macmillan, 1989), p.48.

${ }^{72}$ Hennessy, Having it so Good, p.468.

73 'Comment: 80 Days', Daily Mail, 5.4.1957.

74 'Britain pins faith to missiles', Manchester Guardian, 5.4.1957.

75 'New model', Manchester Guardian, 5.4.1957.

${ }^{76}$ NA, HO 322/135. Town Clerk, Metropolitan Borough of Saint Pancras to the Under Secretary of State, Home Office, 11.4.1957.
} 
paragraphs dealing with civil defence would have been sufficient to safeguard the position, but even in the short time since the publication of the White Paper, it has become increasingly clear that this is not sufficient'. St Pancras was 'the most extreme example of this'. What was more, the Metropolitan Borough called on other local authorities to do the same and impress upon the Government 'the urgency of abolishing all atomic and hydrogen bombs as the only means of abolishing the wholesale slaughter of people in future wars'. ${ }^{77}$ Desperate to restrict the malign influence of the 'Communist-controlled' council, ${ }^{78}$ Butler implored Sandys to stress the validity of civil defence and quash the 'indefensible' current of argument in the next day's Commons defence debate; but although Sandys added a brief section on civil defence to his speech, he merely echoed the White Paper and failed to adequately expound civil defence. He did at least stress that 'the nation's available resources should be concentrated not on preparations to wage war so much as on trying to prevent this catastrophe from ever happening, ${ }^{79}$ but this hardly suited Butler's purpose.

Butler himself swiftly moved to crush the St Pancras 'rebellion' in order to stop the 'embarrassment' of other local authorities following suit. ${ }^{80}$ But although the issue of St Pancras Council's non-compliance was resolved swiftly, with a Commissioner being appointed to undertake the Council's civil defence functions, ${ }^{81}$ it was an embarrassing episode which generated a deal of adverse publicity for the Government's defence policy. Moreover, it seemed to immediately prove the validity of Home Office concerns regarding support for the government's defence policy. Although a look at the press reaction should have placated the Home Secretary, as the Daily Telegraph and the News Chronicle gave ample space to critics of the St Pancras move, ${ }^{82}$ it was a grim warning of the future, as opponents of the Conservative Government's nuclear policy made use of its own published information to launch attacks - especially that single sentence in the Sandys White Paper. It recurred, in mutated form, as a terrible coda damning the Government's policy, reaching its apotheosis early in 1958 when the Campaign for Nuclear Disarmament was formed in London.

\footnotetext{
77 NA, PREM 11/4155. Butler to Sandys, 15.4.1957.

${ }^{78}$ Ibid, Butler to Macmillan, 10.12.1957.

${ }^{79}$ House of Commons, Parliamentary Debates, Vol.568, cols.1760-5.

${ }^{80}$ NA, PREM 11/4155. Butler to Sandys, 15.4.1957.

${ }^{81}$ NA, HO 322/135. F.A. Newsam to the Town Clerk, St Pancras Borough Council, 27.5.1957.

82 'St Pancras may drop civil defence', Daily Telegraph, 16.4.1957; 'Row brews on civil defence', News Chronicle, 16.4.1957.
} 
It is standard for historians of the nuclear disarmament movement to stress the importance of the Sandys White Paper in inspiring the groundswell of opinion which occurred in 1957-58. ${ }^{83}$ The origins of CND are complex - the movement coalesced from other groups, especially those campaigning against nuclear testing. The 1957 White Paper was one of two key events. By stressing Britain's adherence to a deterrent strategy, it made British use of hydrogen bombs seem much more likely; also, rationalising nuclear weapons and seeking to integrate them with 'normal' weapons seemed immoral to some. The second key event was Nye Bevan's famous 'emotional spasm' speech at that year's Labour Conference. ${ }^{84}$ By ruling out unilateralism Bevan essentially 'disenfranchised' its supporters - without the Labour Party, the disarmers had to stand alone and speak for themselves. What is not so well understood was the importance of the civil defence debate in allowing opponents of the Government's nuclear policy to frame their criticisms. In an obvious way, for the councillors of St Pancras (or Coventry), stopping local civil defence measures was the only way of striking at the Government. By flagging its 'pointlessness', they were highlighting the contradictions in the Government's civil defence policy, questioning the worth of nuclear weapons if they presaged total destruction for all. Early CND propaganda did much the same thing. For example, a 1958 pamphlet by unilateralist historian A.J.P. Taylor made much of the admission: 'there is no defence against the H-bomb, according to the Minster of Defence. No preparation can be made to secure the civilian population. And it is official policy that none can be made' ${ }^{85}$ A major element of CND's success, in historian Meredith Veldman's words, 'was to convince ordinary individuals that they knew better than the experts, that the almost instinctive emotional revulsion against the idea of nuclear war should be trusted as much as or more so than any strategic calculations' ${ }^{86}$ Using the White Paper's admission as a didactic tool allowed the disarmers to promote their 'populist moralism', ${ }^{87}$ ridiculing politicians in the process. From St Pancras to early CND, the Sandys White Paper's admission that

\footnotetext{
${ }^{83}$ See L.S. Wittner, Resisting the Bomb: A History of the World Nuclear Disarmament Movement,195470, (Stanford: Stanford UP, 1997), p.45; P. Byrne, The Campaign for Nuclear Disarmament, (New York: Croom Helm, 1988), p.43; R. Taylor, Against the Bomb: The British Peace Movement, 1958-1965, (Oxford: Clarendon, 1988), p.19n.

84 'Unilateral ban on nuclear weapons rejected', The Times, 4.10.1957.

${ }^{85}$ A.J.P. Taylor, The Deterrent Myth, (London: CND, 1958), p.1.

${ }^{86}$ M. Veldman, Fantasy, the Bomb, and the Greening of Britain: Romantic Protest, 1945-80, (Cambridge UP, 1994), p.202.

${ }^{87}$ Taylor, Against the Bomb, p.43.
} 
the bomber will always get through was turned into an admission that civil defence was useless and that nuclear exchange would cause utter annihilation, which of course underpinned CND's fundamental case that the bomb was both immoral and insane. ${ }^{88}$

The changes to home defence policy during the $1955-57$ period sought to make civil defence more relevant and cost-effective in the new thermonuclear ear. Gone were expensive measures and in came the rhetoric of 'insurance' and deterrence. In terms of actual saving of lives, civil defence in the years after Sandys rested on the idea of selfhelp, aided by a warning system which would at least give the public the chance of survival. In the areas of peripheral damage, it was hoped, the Civil Defence Corps would have a rescue role. Two key elements in this new doctrine were the Royal Observer Corps (ROC), and the new United Kingdom Warning and Monitoring Organisation, the successor to the Air Raid Warning Organisation. The ROC were given the role of monitoring fallout during a hydrogen bomb attack - an activity very different from the aeroplane spotting the ROC enthusiasts had trained, and signed up, for. ${ }^{89}$ This role, however, was controversial, with some volunteers resigning and the Air Ministry becoming concerned about a crisis of recruitment. ${ }^{90}$ Although volunteers were seemingly concerned with the ROC 'losing its identity and becoming a remote offshoot of the Civil Defence Corps', ${ }^{91}$ without its new civil defence role, the Royal Observer Corps would have been left strategically and tactically obsolete by the end of the decades. The warning organisation, which had been given the role of providing the public with warnings in $1956,{ }^{92}$ was restructured to take into account the ROC's new role. Although its new headquarters were part of the Home Office, the ROC remained institutionally part of the Air Ministry. In 1959, in the midst of a row about paying for the ROC, both the Air Minsitry and the Home Office recognised that although only 290 out of 1,550 ROC posts were needed for the purposed of identifying low-flying aeroplanes, the ROC needed to maintain its traditional link with RAF to avoid destroying its morale. ${ }^{93}$

\footnotetext{
${ }^{88}$ For the Government's limited attempt to answer the disarmers' criticisms and promote civil defence see Grant, 'Civil Defence Policy'.

${ }^{89}$ Ministry of Defence, Statement of Defence, 1956, Cmd.9691 (London: HMSO, 1956), p.26.

${ }^{90}$ NA, AIR 2/14564. S.C. Widdows to Vice Chief of the Air Staff, 14.9.1956.

${ }^{91}$ See D. Wood, Attack Warning Red: the Royal Observer Corps and the Defence of Britain, 1925-75 (London: Macdonald and Jane's, 1976), p.225.

${ }^{92}$ Ministry of Defence, Statement of Defence, 1956, p.26.

${ }^{93}$ NA, AIR 2/14592. F.W. Verryto D. McKean, 15.10.1959.
} 
The importance of the new warning system in saving lives was outlined in a 1959 Home Office pamphlet, ${ }^{94}$ but little else was said about civil defence in the years following Sandys. An illustrative case was provided by the intervention of Harold Macmillan, who in September 1958 was dissatisfied with civil defence spending concentrating on the Civil Defence Corps when it clearly would not save many lives. ${ }^{95}$ When the possibility of scrapping the Corps was raised, however, the Defence Committee decided it was safer to do nothing, because 'any change in the existing policy, whether directed to expanding or curtailing the limited preparations already being made, would be liable to attract attention and so to provoke discussion of an issue to which public opinion appeared at present to be remarkably indifferent'. Instead, the government would continue to 'acquiesce' in the policy's 'fundamental illogicality... realising that its main purpose was to maintain the morale of the population rather than to provide them with any effective protection against nuclear attack'. ${ }^{96}$ This belief that civil defence should be left well alone, and that the Corps needed to continue for morale rather than lifesaving purposes, was upheld during a thoroughgoing review of civil defence which lasted for much $1960 .{ }^{97}$ In this sense, the compromise policy thrashed out in 1956 and enshrined in Sandys determined the civil defence agenda until well into 1960s.

\section{Conclusion}

The home defence paradigm of the Sandys White Paper has been an ill-understood element of British defence history. Key paragraphs from the document had a major impact on British society and on public perceptions of British nuclear policy. Also, the origins of those paragraphs lie in a fiercely contested Whitehall debate concerning the necessity of home defence measures in the thermonuclear age. The wider strategic decisions made in the course of 1956 seemed to allow the cuts in home defence provision which economic circumstances made so desirable. The civil defence portion of the White Paper's savings was crucial. Overall, only $£ 78$ million was reduced from the 1956/57 figures: home defence alone was reduced by more than $£ 22$ million on the previous year. Yet justifying that saving proved contentious, with the Minister of Defence arguing for admitting that home defence served no other role than supporting the deterrent and that 'survival' measures had been abandoned (hence the saving); the

\footnotetext{
${ }^{94}$ Home Office, Radioactive Fall-Out: Provisional Scheme of Public Control, (London: HMSO, 1959).

${ }^{95} \mathrm{NA}, \mathrm{CAB} 131 / 19$. D(58) $18^{\text {th }}$ Meeting, 10.9.1958.

${ }^{96}$ Ibid.

${ }^{97} \mathrm{NA}, \mathrm{CAB} 134 / 2039$. HDR(60)4 $4^{\text {th }}$ Meeting (confidential annex), 2.5.1960.
} 
Home Secretary, on the other hand, counselled that such an argument would encourage 'defeatism' and invite criticism, instead suggesting maintaining the fiction of survival measures and justifying reductions on economic grounds (thus allowing the Government to continue to 'encourage' civil defence). In the final paper, a mixed approach was taken, stressing the need for home defence but also admitting that there was no real prospect of protection. Unsurprisingly, one effect of the Paper was the long-term opprobrium of the nuclear disarmers, as predicted by Gwilym Lloyd-George.

Sandys was an important document in the history of civil and home defence, but civil and home defence was also of vital importance in the shaping, reception and legacy of the White Paper itself. As soon as it was published, criticism of the Government's new deterrent policy began in the form of attacks on the lack of civil defence preparations, or rather their worthlessness. Civil defence was the entry point for critics of the new strategy as its apparent absence demonstrated the flaws in the plan: any use of Britain's 'deterrent' would bring automatic and utter destruction. In vain the Government protested that civil defence remained a key policy, but the lack of real belief in the measures within Whitehall was palpable. Perhaps the most famous sentence ever to appear in a Defence White Paper was routinely misquoted - and always quoted out of context - but it did appear to sum up the spirit of the White Paper and the Government's attitude to civil defence as thrashed out in 1956. In this sense, Gwilym Lloyd-George was right and the reality of the government's thinking on civil defence would become widely understood. Successive Ministers of Defence, however, were also proved correct in the sense that disarmament never came close to becoming a majority opinion amongst the British public and that once explained, it seem, the deterrent strategy was understood and supported.

\section{$\underline{\text { References }}$}

S. J. Ball, 'Harold Macmillan and the Politics of Defence: the Market for Strategic Ideas during the Sandys Era Revisited', Twentieth Century British History, 6:1 (1995), 78-100.

C. Brooker, The Neophiliacs, (London: Collins, 1969).

P. Byrne, The Campaign for Nuclear Disarmament, (New York: Croom Helm, 1988).

M. Carver, Tightrope Walking: British Defence Policy since 1945, (London:

Hutchinson, 1992).

P. Catterall (ed.), The Macmillan Diaries, (London: Pan, 2004). 
M. Grant, 'Civil Defence Policy in Cold War Britain, 1945-68'. Unpublished PhD Thesis, Queen Mary, University of London, 2006.

P. Hennessy, The Secret State: Whitehall and the Cold War, (London: Penguin, 2003).

P. Hennessy, Having it So Good: Britain in the Fifties, (London: Penguin, 2006).

Home Office, Radioactive Fall-Out: Provisional Scheme of Public Control, (London: HMSO, 1959).

A. Horne, Macmillan: 1957-1986, (London: Macmillan, 1989).

J. Hughes, 'The Strath Report: Britain Confronts the H-Bomb, 1954-5', History and Technology, 19:3 (2003), pp.257-75.

Ministry of Defence, Statement on Defence, 1955, Cmd.9391, (London: HMSO, 1955). Ministry of Defence, Statement of Defence, 1956, Cmd.9691 (London: HMSO, 1956)

Ministry of Defence, Defence: Outline of Future Policy, Cmnd.124, (London: HMSO, 1957).

M. S. Navias, 'Terminating Conscription? The British National Service Controversy, 1955-56', Journal of Contemporary History, 24:2 (1989), 195-208.

M. S. Navias, Nuclear Weapons and British Strategic Planning, 1955-58, (Oxford: Clarenden, 1991).

T. O’Brien, Civil Defence, (London: HMSO, 1955).

K. Ruane and J. Ellison, 'Managing the Americans: Anthony Eden, Harold Macmillan and the Pursuit of "Power-by-Proxy" in the 1950s', Contemporary British History, 18:3 (2004), 147-67.

A.J.P. Taylor, The Deterrent Myth, (London: CND, 1958).

R. Taylor, Against the Bomb: The British Peace Movement, 1958-1965, (Oxford: Clarendon, 1988).

M. Veldman, Fantasy, the Bomb, and the Greening of Britain: Romantic Protest, 194580, (Cambridge UP, 1994).

R. Weight, Patriots: National Identity in Britain, 1940-2000, (London: Pan, 2003).

L.S. Wittner, Resisting the Bomb: A History of the World Nuclear Disarmament Movement, 1954-70, (Stanford: Stanford UP, 1997).

D. Wood, Attack Warning Red: the Royal Observer Corps and the Defence of Britain, 1925-75 (London: Macdonald and Jane's, 1976) 